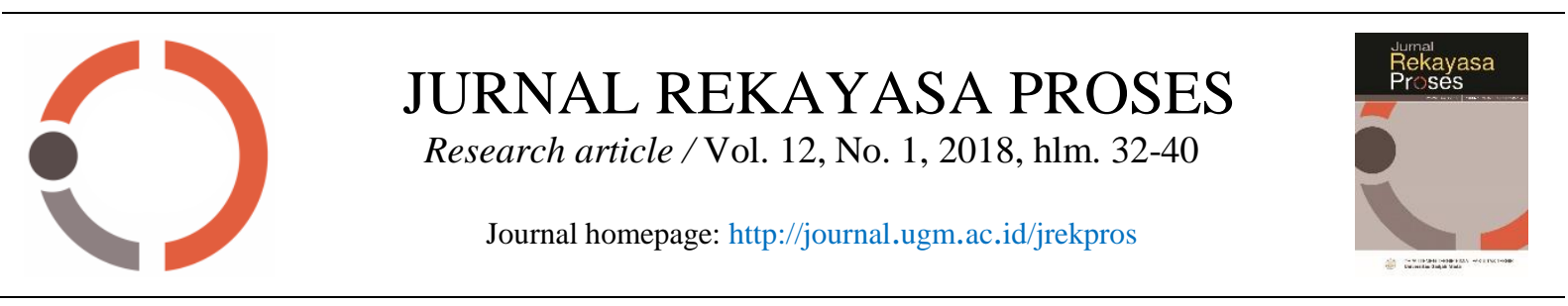

\title{
Kinerja dan Kinetika Produksi Biohidrogen secara Batch dari Sampah Buah Melon dalam Reaktor Tangki Berpengaduk
}

\author{
Febrina Sarlinda ${ }^{1}$, Sarto $^{2}$, dan Muslikhin Hidayat ${ }^{2}$ \\ ${ }^{1}$ Jurusan Kesehatan Lingkungan, Politeknik Kesehatan Tanjungkarang \\ ${ }^{2}$ Program Studi Teknik Kimia, Fakultas Teknik, Universitas Gadjah Mada \\ Jl Grafika No. 2 Kampus UGM, Yogyakarta, 55281 \\ *Alamat korespondensi: febrina.sarlinda@mail.ugm.ac.id
}

(Submisi: 1 Maret 2018; Revisi: 14 Mei 2018; Penerimaan: 18 Mei 2018)

\section{A B S T RACT}

Melon fruit waste with high sugar and water content is potential as a substrate for hydrogen production by dark fermentation. This study investigated the performance of biohydrogen production

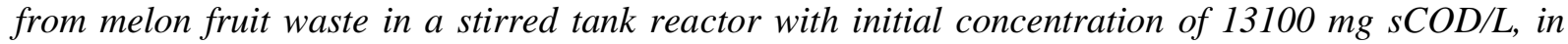
room temperature, initial $\mathrm{pH}$ of 7 and controlling final $\mathrm{pH}$ at 5.5 by adding $\mathrm{NaOH}$. The fermentation was carried out for 24 hours. The value of $\mathrm{pH}$, volatile solid (VS), soluble chemical oxygen demand (sCOD), volatile fatty acid (VFA), biogas volume, hydrogen content, and cell concentration was analized every hour to determine the performance of reactor. Hydrogen content reached $16.20 \%$ with hydrogen production rate $(H P R)$ of $458.12 \mathrm{~mL} / \mathrm{L}_{\text {reactor }}$ /day in the standard temperature and pressure (STP) condition. Substrate consumption at the end of fermentation reached $24.61 \%$ of $S C O D$ and $78.28 \%$ of VS. Metabolite products were dominated by acetate and butyrate with butyrate to acetate ratio of 7:6. The kinetic of product formation was evaluated by the kinetic model of Gompertz. Meanwhile the kinetics of cell growth was approximated by logistics model

\section{Keywords: melon fruit waste, stirred tank reactor, HPR, kinetics}

\section{A B S T R A K}

Sampah buah melon yang cukup melimpah dan kaya akan gula dan air sangat berpotensi sebagai substrat untuk produksi biohidrogen secara fermentasi gelap. Pada penelitian ini dipelajari kinerja produksi biohidrogen dari sampah buah melon menggunakan reaktor tangki berpengaduk. Konsentrasi awal substrat $13.100 \mathrm{mg} \mathrm{sCOD/L} \mathrm{pada} \mathrm{suhu} \mathrm{ruang,} \mathrm{pH}$ awal 7 dan dan dilakukan kontrol terhadap $\mathrm{pH}$ akhir fermentasi agar tidak turun lebih rendah dari $\mathrm{pH}$ 5,5 dengan penambahan $\mathrm{NaOH}$. Fermentasi berlangsung selama 24 jam dan setiap jam dilakukan analisis terhadap $\mathrm{pH}$, volatile solid (VS), soluble chemical oxygen demand ( $S C O D$ ), volatile fatty acid (VFA), volume biogas, kadar hidrogen dan konsentrasi biomassa untuk mengetahui kinerja reaktor. Kadar biohidrogan yang diperoleh sebesar $16,20 \%$ dengan laju produksi hidrogen sebesar $458,12 \mathrm{~mL} / \mathrm{L}_{\text {reaktor }} /$ hari pada keadaan STP. Konsumsi substrat pada akhir fermentasi mencapai $24,61 \%$ sCOD dan 78,28\% VS. Produk metabolit dominan adalah asetat dan butirat dengan ratio butirat per asetat sebesar 1,2. Kinetika pembentukan hidrogen dipelajari melalui model kinetika persamaan Gompertz. Sedangkan kinetika pertumbuhan sel didekati dengan model kinetika persamaan logistik.

Kata kunci: sampah buah melon, reaktor tangki berpengaduk, laju produksi hidrogen, kinetika 


\section{Pendahuluan}

Salah satu komoditas buah yang cukup besar di Indonesia adalah melon (Cucumis melo L). Menurut data statistik Food and Agricultural Organization (FAO) produksi melon secara global selalu meningkat dari tahun ke tahun. Pada tahun 2014 produksi melon dunia mencapai 29.626.335 ton, sedangkan produksi melon Indonesia mencapai 150.356 ton. Dengan memperhitungkan bahwa $10 \%$ dari total produksi buah akan menjadi sampah, potensi sampah dari buah melon sangat besar. Selain itu, hal ini ditunjang dengan karakteristik sampah buah melon yang kaya karbohidrat, yang terdiri dari gula-gula sederhana yang mudah diuraikan dan kadar air yang mencapai $90,15 \%$ berat (USDA, 2017). Oleh karena itu, sampah buah melon sangat ideal dijadikan substrat untuk produksi energi alternatif secara fermentasi. Salah satu energi alternatif masa depan adalah biohidrogen. Pembakaran hidrogen hanya menghasilkan uap air dan dapat diproduksi dari berbagai jenis substrat organik terbarukan secara fermentasi gelap. Proses fermentasi gelap memiliki beberapa keuntungan antara lain tidak membutuhkan cahaya, proses yang lebih praktis dan aplikatif, biaya produksi yang rendah apalagi ketika substrat yang digunakan berasal dari sampah organik (Kim dkk., 2011) seperti sampah buah.

Pemanfaatan sampah buah melon sebagai substrat untuk produksi biohidrogen telah dilakukan oleh beberapa peneliti terdahulu. Cahyari dkk. (2013) pada penelitian secara batch tanpa kontrol $\mathrm{pH}$ dengan variasi konsentrasi 2-18 g VS/L melaporkan pada konsentrasi substrat di atas $6 \mathrm{~g} \mathrm{VS} / \mathrm{L}$ produksi hidrogen menurun karena penurunan pH sistem. Ameekan (2014) mempelajari pengaruh asal inokulum terhadap produksi biohidrogen secara batch. Ia melaporkan bahwa yield hidrogen tertinggi dihasilkan ketika menggunakan campuran inokulum dari sludge biodigester sampah buah dan sludge digester kotoran sapi. Penelitian yang mempelajari performa fermentasi secara kontinu menggunakan substrat buah-buahan maupun kulit buah telah lebih banyak dilakukan antara lain oleh Vijayaraghavan (2007), Feng dkk., (2010),
Akinboni dan Taherzadeh (2015), serta Nurkholis (2017).

Studi kinetika yang melibatkan substrat buah pernah dilakukan oleh Nathoa dkk. (2014) menggunakan substrat kulit pisang pada reaktor batch tanpa pengadukan. Penelitian ini hanya menggunakan pendekatan model persamaan Gompertz dan hanya untuk mengetahui parameter kinetika produk gas. Sedangkan kinetika pertumbuhan bakteri dari substrat buah melon pernah dipelajari oleh Nurkholis (2017). Pada penelitian tersebut digunakan reaktor pipa tanpa adanya kontrol $\mathrm{pH}$ dengan campuran inokulum sludge biodigester kotoran sapi, ampas tahu, dan sampah buah. Perilaku dan laju produksi biohidrogen akan berbeda bergantung pada karakteristik substrat, jenis reaktor, dan kondisi operasi. Sementara itu kinerja produksi biohidrogen dari sampah buah melon dalam reaktor tangki berpengaduk dengan melakukan kontrol $\mathrm{pH}$ pada $\mathrm{pH}$ 5,5 serta studi kinetika pembentukan produk dan pertumbuhan sel bakteri yang menyertainya belum pernah dilaporkan sebelumnya. Parameter kinerja reaktor pada penelitian ini dilihat dari jumlah substrat yang mampu diuraikan, laju produksi gas dan kadar hidrogen yang dihasilkan. Kinetika produksi hidrogen didekati dengan persamaan Gompertz, sedangkan kinetika pertumbuhan bakteri didekati dengan persamaan logistik.

\section{Metode Penelitian}

\subsection{Bahan Penelitian}

Bahan-bahan yang digunakan dalam penelitian ini adalah sampah buah melon yang diperoleh dari Pasar Buah dan Sayur Gemah Ripah, Gamping, Kabupaten Sleman, Yogyakarta. Inokulum diperoleh dari campuran sludge biodigester sampah buah di Pasar Buah dan Sayur 'Gemah Ripah', Gamping, Kabupaten Sleman, Yogyakarta. Sludge biodigester kotoran sapi diperoleh dari Pusat Inovasi Agroteknologi (PIAT) UGM, Berbah, Kabupaten Sleman, Yogyakarta, aquadest, $\mathrm{HCl} 37 \%$ p.a. (Merck), $\mathrm{NaOH}$ p.a. (Merck), pepton (Merck), yeast extract (Merck), glukosa (Merck), $\mathrm{KH}_{2} \mathrm{PO} 4$ (Merck), $\mathrm{Na}_{2} \mathrm{HPO} 4$ p.a. (Merck), $\mathrm{MgSO}_{4} \cdot 7 \mathrm{H} 2 \mathrm{O}$ 
p.a. (Merck), $\mathrm{NaHCO}_{3}$ p.a. (Merck), resazurin (Sigma Aldrich), L-Cystein-HCl (Merck), gas $\mathrm{N}_{2}$ dan alkohol 96\%, $\mathrm{HgSO}_{4}$ (Merck), dan $\mathrm{Ag}_{2} \mathrm{SO}_{4}$ (Merck).

\subsection{Alat Penelitian}

Alat yang digunakan dalam penelitian ini disajikan pada Gambar 1. Reaktor tangki berpengaduk berupa erlenmeyer berukuran 3 liter yang telah dimodifikasi dan dilengkapi dengan $\mathrm{pH}$ meter dan pengukur gas (water displacement method).

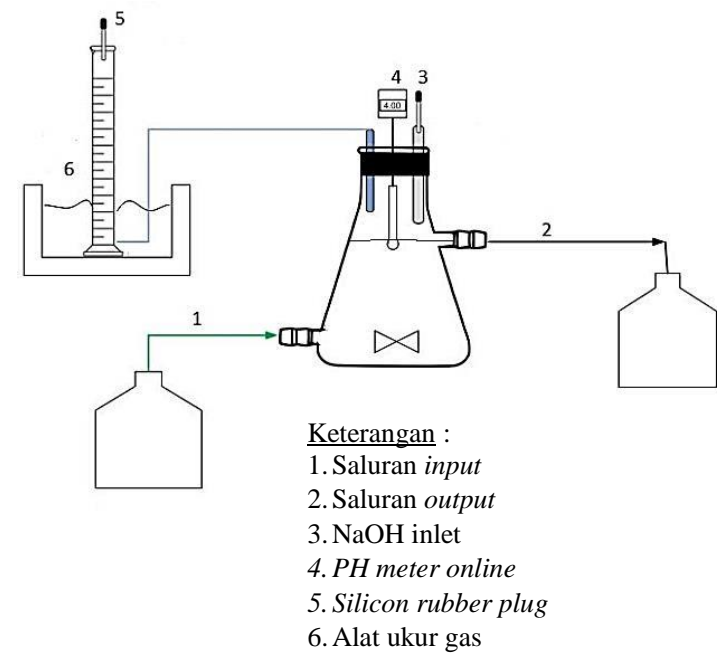

Gambar 1. Rangkaian alat penelitian

\subsection{Cara Penelitian}

\subsubsection{Persiapan Inokulum}

Pada inokulum dari sludge biodigester biogas sampah buah dan kotoran sapi dilakukan pretreatment dengan pengasaman hingga $\mathrm{pH} 3$ selama 24 jam menggunakan $\mathrm{HCl} 2 \mathrm{~N}$. Perlakuan ini bertujuan supaya bakteri metanogen menjadi tidak aktif dan bakteri penghasil hidrogen membentuk spora (Ruggeri dkk., 2013). Selanjutnya dilakukan aktivasi dan pengayaan dengan memindahkan inokulum ke dalam medium Pepton-yeast-glucose (PYG) dengan komposisi $10 \mathrm{~g} / \mathrm{L}$ pepton, $10 \mathrm{~g} / \mathrm{L}$ yeast extract, 10 g/ L glukosa selama 3 kali siklus 24 jam.

\subsubsection{Persiapan Substrat}

Sampah buah melon dihaluskan dengan menggunakan blender dan disimpan di dalam kulkas dengan suhu di bawah $4{ }^{\circ} \mathrm{C}$ hingga siap untuk digunakan untuk mencegah terjadinya pembusukan lebih lanjut. Kulit dan biji melon tidak digunakan dalam penelitian ini. Kulit melon mengandung senyawa antimikroba eugenol (Aubert dan Pitrat, 2006) yang dapat menghambat proses fermentasi sedangkan biji melon sangat keras dan mengandung minyak (Fasogbon, 2015) yang sulit untuk diuraikan.

\subsubsection{Produksi biohidrogen}

Campuran yang terdiri dari 30\% substrat sampah melon, $10 \%$ inokulum mikroba campuran, dan $60 \%$ medium produksi (pepton 5 $\mathrm{g} / \mathrm{L} ;$ yeast extract $0.5 \mathrm{~g} / \mathrm{L} ; \mathrm{KH}_{2} \mathrm{PO}_{4} 1.2 \mathrm{~g} / \mathrm{L}$; $\mathrm{Na}_{2} \mathrm{HPO}_{4} \quad 5.1 \mathrm{~g} / \mathrm{L} ; \quad \mathrm{MgSO}_{4} .7 \mathrm{H}_{2} \mathrm{O} \quad 0.5 \mathrm{~g} / \mathrm{L} ;$ $\mathrm{NaHCO}_{3} 3 \mathrm{~g} / \mathrm{L}$; Resazurin $1 \mathrm{mg} / \mathrm{L}$; L-cystein $\mathrm{HCl}$ $0.5 \mathrm{mg} / \mathrm{L}$ ) dimasukkan ke dalam reaktor tangki berpengaduk lalu di-flushing dengan gas nitrogen untuk mendapatkan kondisi anaerob. Reaktor beroperasi pada suhu ruang dan tekanan atmosferik. $\mathrm{pH}$ awal adalah 6,85 dengan konsentrasi awal susbtrat $13.100 \mathrm{mg}-\mathrm{sCOD} / \mathrm{L}$. Nilai $\mathrm{pH}$ operasi dijaga agar tidak turun di bawah 5,5 dengan penambahan $\mathrm{NaOH} 5 \mathrm{~N}$ ketika $\mathrm{pH}$ mulai drop. Pengamatan dilakukan selama 24 jam dan dilakukan pengambilan sampel gas dan cairan setiap jam.

\subsubsection{Model Kinetika}

Pendekatan matematis dilakukan dengan mengasumsikan kultur bakteri sebagai pseudomonoculture, pseudosingle substrate dan laju produksi biogas disumsikan sebanding dengan laju pertumbuhan bakteri (associated growth product formation) sehingga yield produk merupakan fungsi dari pertumbuhan bakteri.

\subsubsection{Kinetika Pembentukan Hidrogen}

Kinetika produksi hidrogen mengikuti model persamaan modifikasi Gompertz (Gadhamshetty dkk., 2010). Persamaan ini digunakan ketika bakteri mengalami fase lag atau waktu penyesuaian pada kondisi reaktor sebelum akhirnya memproduksi hidrogen. Pada penelitian ini diduga akan terdapat fase lag (fase penyesuaian) pada awal waktu start-up karena ada perbedaan komposisi antara medium enrichment dan kondisi di dalam reaktor. Persamaan modifikasi Gompertz dinyatakan pada Persamaan 1. 


$$
Y=A \exp \left(-\exp \left[\frac{\mu_{m} e}{A}(\lambda-t)+1\right]\right.
$$

dimana:

$Y=$ produksi hidrogen kumulatif per satuan waktu $\left(\mathrm{mLH}_{2} / \mathrm{Lr}_{\text {eaktor }}\right)$,

$A=$ potensi hidrogen maksimum $\left(\mathrm{mLH}_{2} / \mathrm{L}_{\text {reaktor }}\right)$,

$\lambda=$ fase lag (jam),

$\mu_{m}=$ laju pembentukan produk maksimum $\left(\mathrm{mLH}_{2} / \mathrm{Lr}_{\text {eaktor }} / \mathrm{jam}\right)$, dan

$e=$ bilangan Euler (2,71828)

\subsubsection{Kinetika Pertumbuhan Sel Bakteri}

Kinetika pertumbuhan sel didekati dengan persamaan logistik (Mullai dkk., 2014). Persamaan ini diturunkan dengan menganggap laju pertumbuhan bakteri berhubungan dengan jumlah carrying capacity yang tidak digunakan. Pertumbuhan bakteri akan dibatasi oleh produk samping yang bersifat racun bagi perumbuhan bakteri. Persamaan logistik dapat dinyatakan sebagai Persamaan 2:

$$
\mu_{g}=K c \cdot\left(1-\frac{X}{X_{\max }}\right)
$$

dimana:

$\mu_{g}=$ laju pertumbuhan spesifik $\left(\right.$ hari $^{-1}$ )

$K c=$ konstanta carrying capacity $\left(\right.$ hari $\left.^{-1}\right)$

$X=$ konsentrasi sel $(\mathrm{mg} / \mathrm{L})$

$X_{\max }=$ konsentrasi sel maksimum $(\mathrm{mg} / \mathrm{L})$

Reaksi pembentukan biohidrogen secara umum dapat dinyatakan seperti pada Persamaan 3:

$$
\mathrm{COD} \stackrel{X \text { (Bakteri) }}{\longrightarrow} \mathrm{H}_{2}+\mathrm{VFA}+\mathrm{X}
$$

Neraca massa yang digunakan untuk mendapatkan konstanta kinetika persamaan logistik adalah Persamaan 4-6:

$$
\begin{aligned}
& -\frac{d C O D}{d t}=\frac{1}{Y^{\prime} X / C O D} \cdot \mu_{g} X \\
& \frac{d V F A}{d t}=Y_{V F A / x} \cdot \mu_{g} \cdot X \\
& \frac{d H_{2}}{d t}=Y_{H 2 / x} \cdot \mu_{g} \cdot X
\end{aligned}
$$

\subsubsection{Metode Analisis}

Volume gas total diukur dengan water displacement method dan dihitung pada keadaan
STP sedangkan kadar hidrogen dianalisis dengan gas chromatograhpy (GC) Shimadzu GC 8A yang dilengkapi dengan thermal conductivity detector (TDC) dan dual packed column. Konsentrasi volatile solid (VS) diukur dengan dengan metode gravimetri. Soluable chemical oxygen demand (sCOD) diukur melalui metode kolorimetri menggunakan potasium dikromat sebagai oksidator. Volatile fatty acid (VFA) sebagai asam asetat, butirat, dan propionat dianalisis menggunakan gas chromatograhpy (GC) yang dilengkapi detektor flame ionization. Analisis jumlah bakteri dilakukan dengan Petroff Hauser dan diamati dengan mikroskop pentaview dengan perbesaran objektif 40 kali dan okuler 40 kali. Sedangkan analisis data untuk mentukan parameter kinetika dilakukan dengan simulasi menggunakan program Matlab.

\section{Hasil dan Pembahasan}

\subsection{Konsumsi substrat}

Profil penurunan VS dan sCOD selama 24 jam dapat dilihat pada Gambar 2. Nilai sCOD removal tertinggi diperoleh pada jam ke-6 sebesar 35,86\% namun secara kumulatif pada akhir fermentasi hanya mencapai $24,61 \%$. Sementara itu VS removal tertinggi 79,09\% diperoleh pada jam ke-10 tetapi pada akhir fermentasi VS removal menurun menjadi $78,28 \%$. Konsentrasi zat organik yang fluktuatif disebabkan karena zat organik yang terhitung bukan hanya konsentrasi substrat melon saja. Biomassa bakteri juga terhitung sebagai konsentrasi zat organik. Selama proses degradasi anerobik terjadi, sel-sel bakteri yang tumbuh dan berkembang akan terhitung sebagai penambahan konsentrasi VS di dalam reaktor.

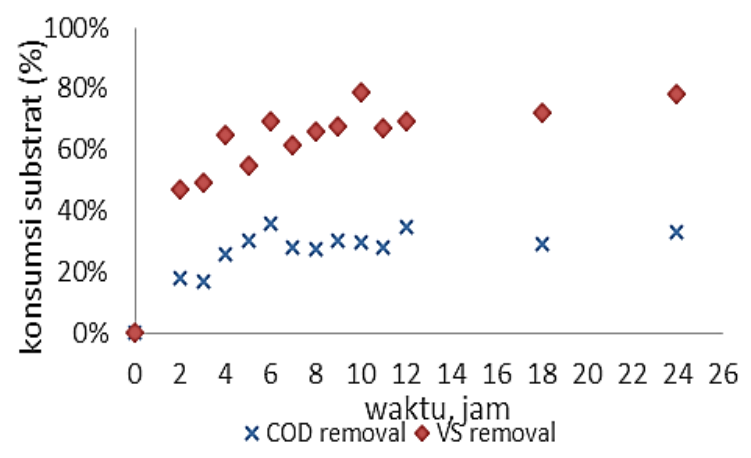

Gambar 2. Profil VS removal dan SCOD removal fase batch 
Di sisi lain sel-sel bakteri tersebut ada pula yang mengalami kematian. Hal ini diduga menjadi salah satu penyebab adanya fluktuasi konsentrasi volatile solid. Sementara itu pada perhitungan sCOD, produk metabolit VFA yang tidak teridentifikasi juga terhitung sebagai sCOD yang mengakibat-kan terganggunya akurasi pengukuran sCOD.

\subsection{Produksi Biogas dan Kadar Hidrogen}

Gambar 3 menunjukkan bahwa produksi gas mulai terlihat setelah jam ke-2 namun volume yang dihasilkan masih sangat kecil. Produksi gas mulai signifikan setelah jam ke-3 dan laju produksi tertinggi dicapai pada jam ke-5 dan selanjutnya menurun hingga jam ke-24. Kadar hidrogen yang dihasilkan berkisar antara $0,72 \%$ 29,65\%. Laju produksi biogas total tertinggi diperoleh pada jam kelima sebesar 803,91 $\mathrm{mL}_{\text {biogas }} / \mathrm{L}_{\text {reaktor }} / \mathrm{jam}$ dan laju produksi hidrogen $81,21 \mathrm{~mL} \mathrm{H}_{2} / \mathrm{L}_{\text {reaktor }} / \mathrm{jam}$.

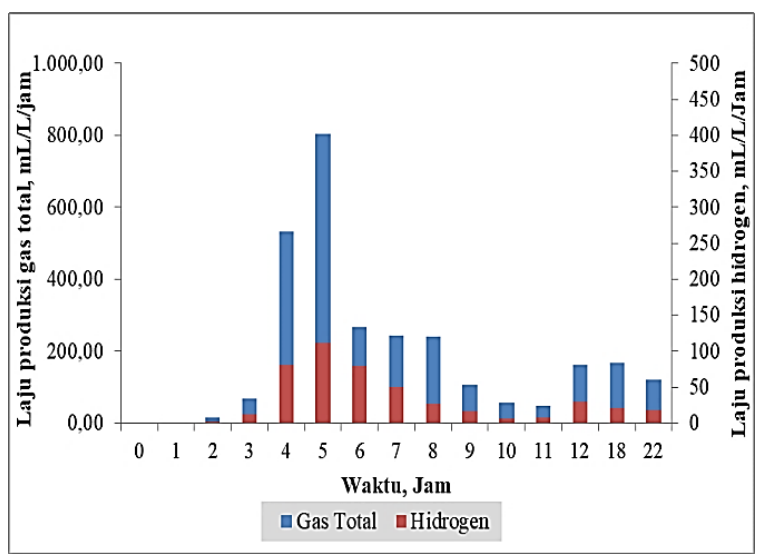

(a)

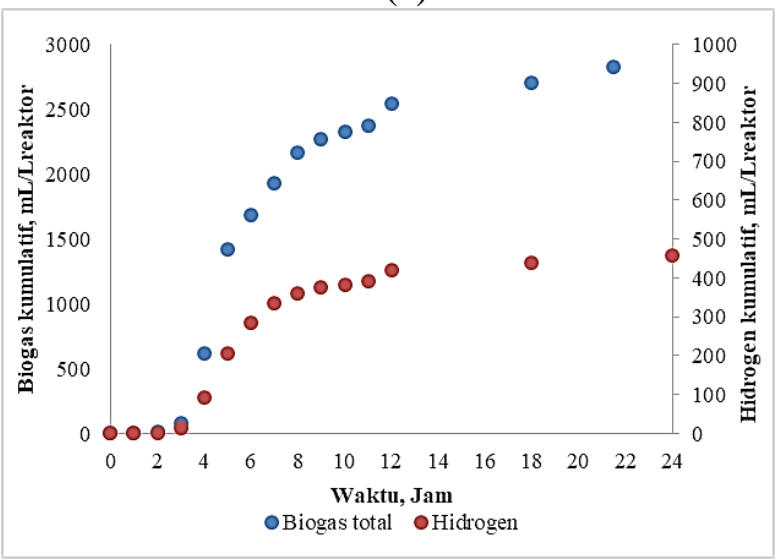

(b)

Gambar 3. Profil laju produksi gas per waktu (a) dan produksi hidrogen kumulatif (b)
Secara kumulatif penambahan biogas total dan produksi hidrogen semakin melambat setelah melewati jam ke-8. Kadar hidrogen selama 24 jam diperoleh sebesar $16,20 \%$ yaitu 458,12 $\mathrm{mLH}_{2} / \mathrm{L}_{\text {reaktor. }}$ Kadar hidrogen tersebut relatif kecil dibandingkan dengan penelitian lain dengan menggunakan kultur mikroba campuran pada kondisi mesofilik dan $\mathrm{pH}$ operasi 5,5. Fang dan Liu (2002) melaporkan kadar hidrogen sebesar 64\% dengan menggunakan substrat glukosa. Sementara itu Khanal dkk (2004) melaporkan kadar hidrogen sebesar $40 \%$ untuk substrat sukrosa dan kadar hidrogen sebesar $25 \%$ untuk substrat pati.

\subsection{Produksi Volatile Fatty Acid (VFA) dan Profil pH}

Volatile Fatty Acid (VFA) merupakan produk metabolit utama dari proses fermentasi gelap secara anaerob. Pembentukan VFA berkorelasi dengan perubahan $\mathrm{pH}$ di dalam reaktor. Semakin tinggi konsentrasi VFA maka $\mathrm{pH}$ di dalam reaktor akan semakin rendah. Pada Gambar 4 terlihat bahwa produksi VFA terus meningkat mulai dari tahap awal fermentasi sampai pada jam ke-6. Hal ini bersesuaian dengan profil produksi gas hidrogen yang juga mengalami kenaikan secara eksponensial mulai dari jam ke-2 sampai dengan jam ke-5. pH di dalam reaktor pun terus-menerus mengalami penurunan hingga mencapai $\mathrm{pH}$ 5,5 pada jam ke5. Selanjutnya profil VFA cenderung fluktutif karena adanya penetralan dengan $\mathrm{NaOH}$.

Produk VFA yang paling dominan dihasilkan adalah asetat dan butirat. Sedangkan asam propionat yang merupakan hasil dari aktivitas bakteri pengonsumsi hidrogen ditemukan dalam jumlah yang sangat sedikit. Hal ini menunjukkan bahwa proses pretreatment mampu menekan aktivitas bakteri pengonsumsi hidrogen. Rata-rata rasio konsentrasi asam butirat dan asam asetat (B/A) setiap jam hanya berkisar 7:6. Rasio ini lebih kecil jika dibandingkan dengan penelitian lain. Ghimire dkk. (2015) melaporkan bahwa fermentasi gelap dengan menggunakan kultur campuran dapat mencapai rasio B/A sebesar 3:2. Semakin besar ratio B/A maka produksi hidrogen akan semakin 
meningkat. Rendahnya rasio $\mathrm{B} / \mathrm{A}$ menjadi alasan rendahnya produksi hidrogen pada penelitian ini. Selain itu rendahnya kadar hidrogen diduga disebabkan karena sejak awal penyiapan inokulum, kemungkinan komunitas bakteri telah didominasi oleh bakteri penghasil hidrogen yang bersifat anaerob fakultatif. Bakteri anerob fakultatif menghasilkan yield yang lebih rendah daripada bakteri anaerob obligat (Balachandar dkk 2013).

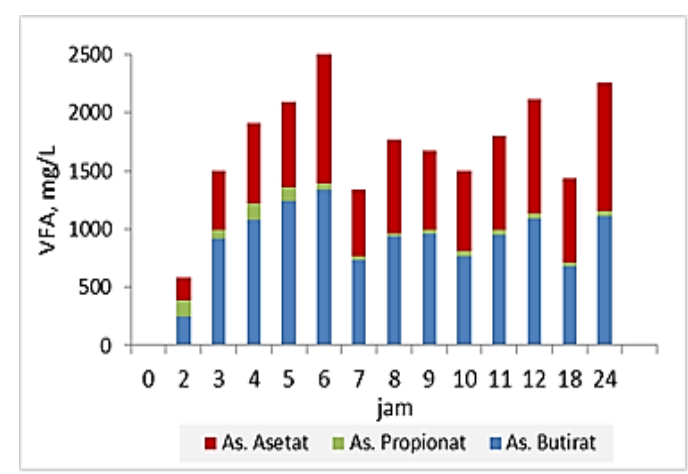

(a)

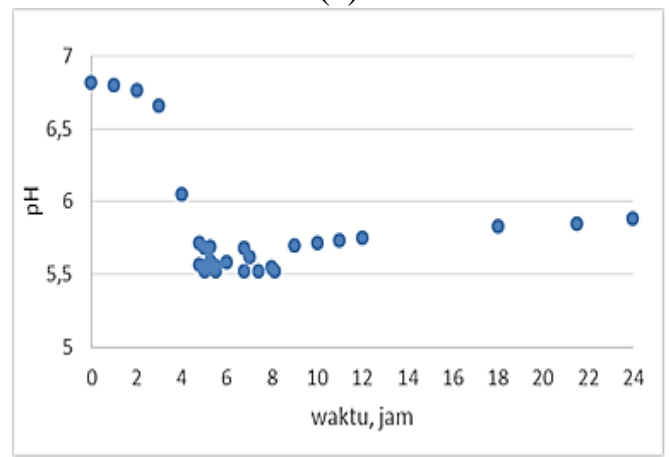

(b)

Gambar 4. Produksi VFA (a), profil perubahan pH (b)

Profil perubahan $\mathrm{pH}$ menunjukkan adanya 3 fase perubahan $\mathrm{pH}$. Sampai dengan jam ke-5 terjadi penurunan $\mathrm{pH}$ secara alamiah di dalam reaktor. Jam ke-5 sampai dengan jam ke-8 terjadi fluktuasi $\mathrm{pH}$ karena pengontrolan dengan penambahan $\mathrm{NaOH}$. Di atas jam ke-8 sampai dengan jam ke-24 perlahan-lahan mulai terjadi kenaikan $\mathrm{pH}$. Kenaikan $\mathrm{pH}$ di atas jam ke-8 disebabkan karena pada saat ini mulai terjadi degradasi protein membentuk nitrogen amoniak. Kehadiran amoniak tersebut mampu meningkatkan kapasitas buffer didalam reaktor yang mencegah terjadinya penurunan $\mathrm{pH}$ (Kim dkk., 2011). Fang dan Liu (2002) melaporkan pH terbaik untuk produksi hidrogen adalah 5,5. $\mathrm{pH}$ operasi yang tidak stabil pada $\mathrm{pH}$ 5,5 ini diduga juga menjadi salah satu alasan rendahnya kadar hidrogen pada penelitian ini. Pengontrolan $\mathrm{pH}$ operasi hanya fokus kepada tujuan agar $\mathrm{pH}$ operasi tidak turun di bawah 5,5, sedangkan $\mathrm{pH}$ operasi sebenarnya pada penelitian ini berada pada kisaran 5,5-6.

\subsection{Kinetika Pembentukan Gas Hidrogen}

Kurva simulasi dari persamaan Gompertz ditunjukkan pada Gambar 5 dan parameter kinetika yang diperoleh ditunjukkan pada Tabel 1. Potensi hidrogen maksimum yang dapat dihasilkan sebesar $423,56 \mathrm{mLH}_{2} / \mathrm{L}_{\text {reaktor, }}$ laju pembentukan hidrogen maksimum diperoleh sebesar $91,78 \quad \mathrm{mLH}_{2} / \mathrm{L}_{\text {reaktor }} / \mathrm{jam}$ dan fase lag selama 2,9 jam. Dibandingkan dengan penelitian sejenis pada Tabel 1 yang juga menggunakan inokulum campuran dengan kondisi operasi yang mirip, nilai $\mathrm{A}$ dan $\mu_{m}$ pada penelitian ini lebih rendah disebabkan oleh konsentrasi awal substrat yang digunakan memang lebih kecil sehingga hidrogen kumulatif yang dihasilkan juga lebih sedikit.

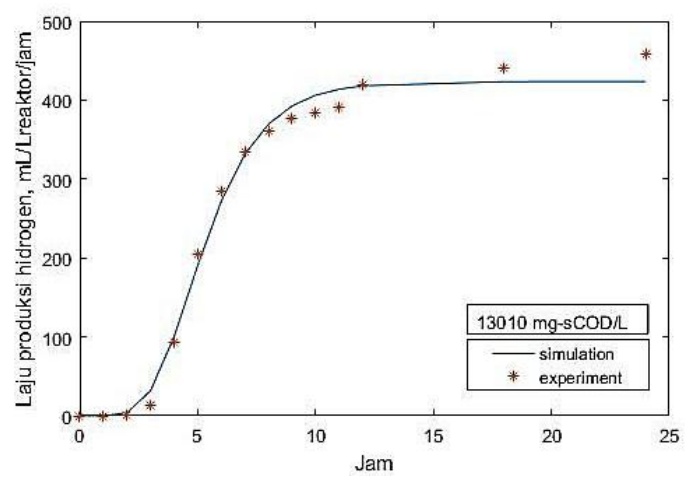

Gambar 5. Kurva simulasi model kinetika persamaan Gompertz

Akan tetapi fase lag yang dibutuhkan pada penelitian ini jauh lebih singkat dibandingkan dengan penelitian lain. Kim dkk (2011) menyatakan bahwa fase lag lebih dipengaruhi oleh $\mathrm{pH}$ awal fermentasi. Pada penelitiannya dilaporkan fase lag sebesar 4,2 jam dengan $\mathrm{pH}$ awal yang sama dengan penelitian ini, yaitu $\mathrm{pH}$ 7. Hal ini disebabkan karena inokulum pada penelitian ini sudah mengalami proses pengayaan dalam medium PYG sebelum digunakan untuk proses produksi sehingga dapat mempersingkat waktu lag. Pengayaan pada medium Pepton- 
Yeast-Glukosa (PYG) pada $\mathrm{pH}$ netral dan diinkubasi pada suhu $37{ }^{\circ} \mathrm{C}$ membuat endospora beradaptasi dengan cepat dan kembali ke fase vegetatifnya. Pada masa pengayaan ini bakteri tumbuh dengan memanfaatkan substrat ideal glukosa sebagai sumber energi sehingga jumlah bakteri penghasil hidrogen akan berkembang pesat. Pengayaan ini mempercepat proses startup di dalam reaktor apabila dibandingkan dengan langsung menggunakan bakteri yang masih dalam bentuk endospora.

Tabel 1. Parameter kinetika persamaan Gompertz

\begin{tabular}{ccccc}
\hline $\begin{array}{c}\text { Konsentrasi } \\
\text { awal }\end{array}$ & $\begin{array}{c}A \\
\left(\mathrm{mLH}_{2} /\right. \\
\left.\mathrm{L}_{\text {reaktor }}\right)\end{array}$ & $\begin{array}{c}\mu_{m} \\
\left(\mathrm{mLH}_{2} /\right. \\
\mathrm{L}_{\text {reaktor }} / \\
\text { jam })\end{array}$ & $\begin{array}{c}\lambda \\
\text { (jam) }\end{array}$ & Peneliti \\
\hline $\begin{array}{c}13.100 \mathrm{mg} / \mathrm{L} \\
30.000 \mathrm{mg} / \mathrm{L}, \\
\mathrm{pH} \text { awal 7 }\end{array}$ & 423,56 & 91,78 & 2,9 & Sarlinda \\
$\mathrm{pH} \mathrm{akhir} \mathrm{5}$ & - & 161 & 4,2 & $\begin{array}{c}\text { Kim dkk. } \\
(2011)\end{array}$ \\
$\begin{array}{c}30.000 \mathrm{mg} / \mathrm{L} \\
\mathrm{pH} \mathrm{5,5}\end{array}$ & - & 201 & 9,5 & $\begin{array}{c}\text { Mu dkk } \\
(2006)\end{array}$ \\
\hline
\end{tabular}

\subsection{Kinetika Pertumbuhan Bakteri}

Hasil simulasi ditunjukkan pada Gambar 6 dan parameter kinetika ditampilkan pada Tabel 2.
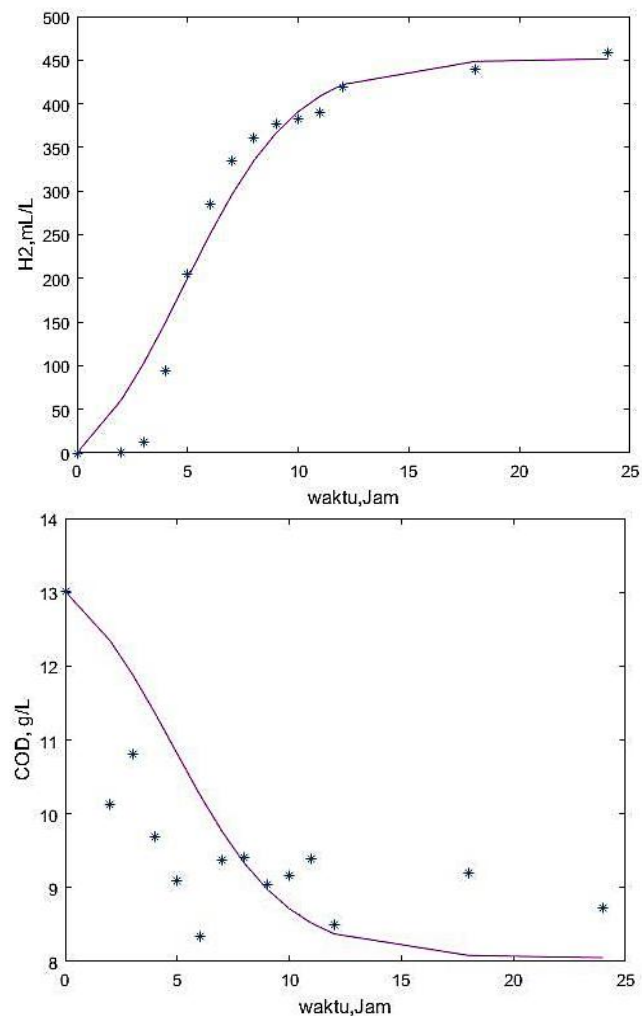

Gambar 6. Kurva simulasi model kinetika dengan model pertumbuhan bakteri persamaan logistik
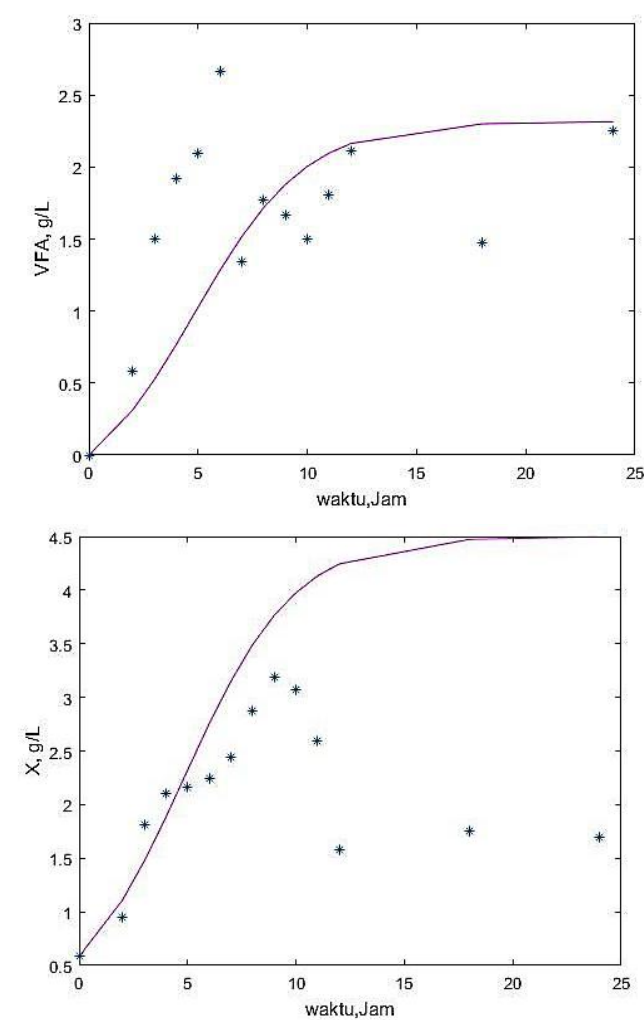

Hasil simulasi menunjukkan data hasil eksperimen dapat dimodelkan dengan cukup baik dengan persamaan logistik. Penyimpangan terjadi pada kurva VFA, sCOD, dan biomassa bakteri (X). Pada kurva VFA hasil simulasi, nilai VFA memiliki kecenderungan meningkat dan mulai steady sejak jam ke-11, sedangkan kurva hasil ekeperimen menunjukkan tren menurun sejak jam ke-7 dan cenderung fluktuatif pada jam-jam selanjutnya. Fluktuasi pada data eksperimen disebabkan oleh adanya reaksi netralisasi akibat penambahan $\mathrm{NaOH}$ sebagai upaya mempertahankan $\mathrm{pH}$ operasi agar tidak turun melebihi $\mathrm{pH}$ 5,5. Penurunan konsentrasi sCOD hasil eksperimen juga cenderung fluktuatif disebabkan karena hasil samping berupa VFA ikut terhitung sebagai sCOD. Nilai sCOD eksperimen hanya dikurangi dengan VFA sebagai asetat, butirat, dan propionat, sedangkan VFA lain yang tidak diukur konsentrasinya masih terhitung sebagai COD. Sehingga nilai COD sebenarnya tanpa VFA akan lebih rendah daripada perhitungan sCOD hasil ekperimen. 
Penyimpangan yang cukup besar terjadi pada kurva biomassa bakteri $(X)$. Jumlah konsentrasi biomassa bakteri masih terus meningkat hingga jam ke-18. Sementara itu data hasil ekperimen menunjukkan tren menurun sejak jam ke-10. Hal ini disebabkan karena penghitungan bakteri secara akurat menggunakan Petroff Hausser setelah jam ke-9 menjadi semakin sulit karena semakin banyak bakteri yang membentuk koloni. Hasil simulasi menunjukkan bahwa untuk mendapatkan produk hidrogen dengan hasil samping VFA dan konsumsi COD sebagaimana data ekperimen, maka jumlah bakteri yang berkembang di dalam rektor seharusnya jauh lebih tinggi daripada data eksperimen.

Tabel 2. Parameter kinetika persamaan logistik

\begin{tabular}{ll}
\hline Parameter & Nilai \\
\hline$K c\left(\mathrm{jam}^{-1}\right)$ & 0,393 \\
$X_{\max }(\mathrm{g} / \mathrm{L})$ & 4,5 \\
$Y_{H 2 / X}\left(\mathrm{~mL} \mathrm{H}_{2} / \mathrm{g} \mathrm{sel}\right)$ & 115,19 \\
$Y_{V F A / X}(\mathrm{~g} \mathrm{VFA} / \mathrm{g} \mathrm{sel})$ & 0,59 \\
$Y_{X / C O D}(\mathrm{~g} \mathrm{sel} / \mathrm{g} \mathrm{COD})$ & 0,79 \\
$K_{d}\left(\mathrm{jam}^{-1}\right)$ & 0,0001 \\
\hline
\end{tabular}

\section{Kesimpulan}

Dari hasil penelitian dapat disimpulkan halhal sebagai berikut:

1. Gas hidrogen yang dihasilkan sebesar 458,12 $\mathrm{mLH}_{2} / \mathrm{L}_{\text {reaktor }}$ yaitu $16,20 \%$ dari total biogas yang diproduksi dengan konsumsi VS sebesar 78,28 \% dan konsumsi sCOD sebesar 24,61\%.

2. Produk metabolit utama yang dihasilkan adalah asetat, butirat dan propionat, dengan rasio (B/A) sebesar 1,2.

3. Kinetika produksi hidrogen dapat didekati dengan persamaan Gompertz dengan parameter kinetika $A=423,5577 \mathrm{mLH}_{2} / \mathrm{L}_{\text {reaktor }}$, $\mu_{m}=91,7810 \quad \mathrm{mLH}_{2} / \mathrm{L}_{\text {reaktor }} / \mathrm{jam}$ dan $\lambda=2,9$ jam.

4. Kinetika pertumbuhan bakteri dapat didekati dengan persamaan logistik dengan nilai parameter kinetika $K c=0,3932$ jam-1, $X_{\max }=$ $4,5 \mathrm{~g} / \mathrm{L}, Y H_{2} / X=115,19 \mathrm{ml} \mathrm{H}_{2} / \mathrm{g}$ sel, $Y_{V F A / X}=$ $0,59 \mathrm{~g} \mathrm{VFA} / \mathrm{g} \mathrm{sel}, Y_{X / C O D}=0,79 \mathrm{~g} \mathrm{sel} / \mathrm{g} \mathrm{COD}$, dan $k_{d}=0,0001 \mathrm{jam}^{-1}$.

\section{Daftar Notasi}

$Y=$ produksi hidrogen kumulatif per satuan waktu $\left(\mathrm{mL} \mathrm{H}_{2} / \mathrm{L}_{\text {reaktor }}\right)$

$A=$ potensi hidrogen maksimum yang dapat dihasilkan ( $\left.\mathrm{mL} \mathrm{H}_{2} / \mathrm{L}_{\text {reaktor }}\right)$

$\mu_{m}=$ laju pembentukan hidrogen maksimum ( $\mathrm{mL} \mathrm{H}_{2} / \mathrm{L}_{\text {reaktorjam) }}$

$\lambda=$ fase lag yang dibutuhkan sebelum terbentuk hidrogen (jam)

$\mu_{g} \quad=$ laju pertumbuhan spesifik $\left(\mathrm{jam}^{-1}\right)$

$K_{c}=$ konstanta carrying capacity $\left(\mathrm{jam}^{-1}\right)$

$X \quad=$ konsentrasi sel $(\mathrm{mg} / \mathrm{L})$

$K_{d}=$ konstanta kematian (jam)

$Y_{H 2 / X}=$ yield hidrogen terhadap jumlah sel bakteri terbentuk ( $\mathrm{ml} \mathrm{H}_{2} / \mathrm{g}$ sel)

$Y_{V F A / X}=$ yield VFA terhadap jumlah sel bakteri terbentuk (g VFA/g sel)

$Y_{X / C O D}=$ yield sel terhadap konsentrasi COD yang dikonsumsi (g sel/g COD)

$X_{\max }=$ konsentrasi sel bakteri maksimum $(\mathrm{g} / \mathrm{L})$

\section{Daftar Pustaka}

Akinboni, J., and Taherzadeh, M. J., 2015, Evaluation of fermentative hydrogen production from single and mixed fruit wastes, Energies, 8(5), 4253-4272

Ameekan, Y., 2014, Pengaruh Perbedaan asal inokulum terhadap produksi hidrogen dari limbah buah melon (Cucumis melo. L) pada fermentor batch, Skripsi, Universitas Gadjah mada.

Anonim, 2017, Basic Report : Nutrient data for 09181, Melons, cantaloupe, raw, Available at: https://ndb.nal.usda.gov/ndb/foods/show/2274 (Accessed at 21 juli 2017)

Aubert, C., and Pitrat, M., 2006, Volatile compounds in the skin and pulp of Queen Anne's pocket melon, J. Agric. Food Chem., 54(21), 8177-8182.

Balachandar, G., Khanna, N., and Das, D., 2013, Biohydrogen Production from Organic Wastes by Dark Fermentation, in Biohydrogen, Elsevier B.V., 1st edition, 103-144 (online book)

Cahyari K., Hidayat M., Sarto, Syamsiah S., 2013, Effect of initial substrate concentration on biohydrogen production from orange and 
melon fruit waste through dark fermentation, the 6th Regional Conf. on Chemical Eng., pp 24 ,

Fang, H.H.P., and Liu, H., 2002, Effect of pH on hydrogen production from glucose by a mixed culture, Bioresour. Technol., 82, 87-93.

Fasogbon, S.K., 2015, Melon oil methyl ester : An environmentatlly friendly fuel, Journal of Natural Resources and Development, 5, 7-53.

Feng X., Wang H., Wang Y., Wang X., and Huang J., 2010, Biohydrogen production from apple pomace by anaerobic fermentation with river sludge', Int. J. Hydrogen Energy, 35(7), 3058-3064.

Gadhamshetty V., Arudchelvam Y., Nirmalakhandan N., and Johnson D., 2010, Modeling dark fermentation for biohydrogen production: ADM1-based model vs. Gompertz model, Int. J. Hydrogen Energy, 479-490.

Ghimire A., Frunzo L., Pirozzi F., Escudie R., Lens P.N.L., and Esposito G., 2015, A review on dark fermentative biohydrogen production from organic biomass: Process parameters and use of by-products, Appl. Energy, 144, 73-95.

Khanal, S.K., Chen, W.H., Li L., and Sung S., 2004, Biological hydrogen production : Effect of $\mathrm{pH}$ and intermediate product, Int. J. Hydrogen Energy, 29(11), 1123-1131.

Kim D.H., Kim S.H., Jung K.W., Kim M.S., and Shin H.S., Effect of initial pH independent of operational $\mathrm{pH}$ on hydrogen fermentation of food waste, Bioresour. Technol., 102(18), pp. 8646-8652.
Mu Y., Wang G., and Yu H.Q., 2006, kinetic modelling of batch hydrogen production process by mixed anaerobic cultures, Bioresour. Technol., 97 (11), 1302-1307

Mullai P., and Sridevi K., 2014, Cell growth and product formation kinetic of biohydrogen production using mixed concortia by batch process, Int. J. of Chem. Tech. Research, 6 (12), 5125-5130

Nurkholis, 2017, Pengaruh organic loading rate (OLR) dan frekuensi pengumpanan pada produksi biohidrogen dari sampah buah melon (Cucumis melo l.) dengan pengumpanansecara berkala (periodic feeding) menggunakan reaktor alir pipa, Tesis, Universitas Gadjah Mada, Yogyakarta

Nathoa C., Sirisukpoca U., and Pisutpaisal N., 2014, Production of hydrogen and methane from banana peel by two phase anaerobic fermentation, Energy Procedia, 50, 702-710.

Ruggeri B., Tommasi T., and Sanfilippo S., 2013, Biohydrogen \& Biomethane Through Anaerobic Digestion, Green Energy and Technology, 25-36.

Vijayaraghavan K., Ahmad D., and Soning C., 2007, Bio-hydrogen generation from mixed fruit peel waste using anaerobic contact filter Bio-hydrogen generation from mixed fruit peel waste using anaerobic contact filter, Int. J. Hydrogen Energy, 32(18), 4754-4760. 